\title{
Retrato de Alberto TaVares QuANdo Jovem ARTista. UMA REVisitação de Projets 69
}

\section{A Portrait of Alberto Tavares as a Young Artist. REVISITINg Projets 69}

\author{
Osvaldo Manuel Silvestre ${ }^{1}$
}

Resumo: Este ensaio visa revisitar a obra inicial do poeta português Al Berto, sob duas perspetivas diversas mas articuladas: a recuperação da sua produção artística inicial e a forma como a obra tematiza a transição das artes plásticas para a escrita; a presença, no seu livro Projets 69, do modelo do Livro de Artista e do Manual de Instruções, ao serviço da realização de performances e instalações que visam responder ao projeto de intensificação da experiência.

Palavras-chave: Al Berto; contracultura; livro de artista.

Abstract: This essay intends to revisit the initial work of the portuguese poet Al Berto, thus articulating two different perspectives: the recovery of his initial artistic production and the way his Oeuvre explores the transition from visual and plastic arts to writing; the presence, in his Projets 69' book, of the Artist Book and the Instructions Manual paradigms, as tools for the production of performances and installations that intend to intensifiy experience.

Keywords: Al Berto; Counterculture; Artist Book.

O tópico que elegi - a obra inicial do poeta português Al Berto, quando ainda não assinava assim e estudava artes plásticas na Bélgica² -

1 Professor do Departamento de Línguas, Literaturas e Culturas, Faculdade de Letras da Universidade de Coimbra, Portugal: <omsilvestre@gmail.com>.

2 Alberto Raposo Pidwell Tavares (1948, Coimbra - 1997, Lisboa) passou a infância e adolescência em Sines, tendo estudado na escola de ensino artístico António Arroio, em 
arrasta alguns problemas que conviria abordar previamente, problemas que estão bem condensados na capa da edição Assírio \& Alvim, em 2002, de Projets 69 (Figura 1): ${ }^{3}$ a obra chama-se agora Projectos 69, e o seu autor dá pelo nome de Al Berto. Contudo, da capa da edição original (admitindo que é essa de 2002) não constam nem autor nem título, mas apenas uma referência institucional: Montfaucon Research Center. Autor e título surgem apenas no bloco textual que ocuparia a p. 1 (Figura 2) e são, respetivamente, Alberto Tavares e Projets 69.

Não desejo abordar aspetos biográficos, para os quais não estou preparado e em relação aos quais mantenho um interesse muito moderado. Mas é inevitável interrogar essa diferença, que não é apenas de nome e idioma, mas, em rigor, de disciplina artística: tudo começa aqui, ou pelo menos parece começar aqui, sendo as questões restantes - o título e a obra redigida quase sempre em francês, o nome ainda desprovido de griffe autoral - um efeito colateral dessa questão. Peço ajuda a essa inesgotável ficção memorial que é Lunário para tentar responder, pelas palavras de Alba, que funcionam como mediação das de Beno:

- Se deixaste de pintar foi porque dizias que a pintura levava muito tempo a executar. E querias sentir o coração das coisas a sangrar, ou explodir a cada segundo. Lembras-te? estavas sempre a dizer coisas destas, ninguém sabia se falavas a sério ou deliravas (AL BERTO, 1999, p. 86).

A última frase de Lunário, que aqui recordo - "Apaga as estrelas, vem dormir comigo no esplendor da noite do mundo que nos foge" (AL BERTO, 1999, p. 161) -, recoloca o drama antes referido ("sentir o coração das coisas a sangrar”) em termos não exatamente idênticos, contudo. A perda, o esplendor da noite do mundo que nos foge, não é agora questão

Lisboa. Em 1967, para não fazer serviço militar, vai para a Bélgica, estudando pintura na École Nationale Supérieure d'Architecture et des Arts Visuels (La Cambre). Vive numa comunidade hippie, na Rue de L’Aurore, é um dos fundadores do Montfaucon Research Center, com pessoas como Joelle de la Casinière e Sophie Podolski, período que revisitará em Lunário, autobiografia ficcionada desse período, de 1988. Regressa a Portugal em novembro de 1974, em plena revolução, e instala-se em Sines, abre uma livraria, cria uma comunidade libertária e funda as Alberto Pidwell Tavares Edições, para a qual cria todo o material gráfico. Esse período foi explorado pelo recente filme de Vicente Alves do Ó, Al Berto (2017), sobre o poeta. Em 1977 edita o primeiro livro, em prosa, À procura do vento num jardim d'agosto, e em 1980, ainda em prosa, Meu fruto de morder, todas as horas. A poesia começa em 1982, com Trabalhos do olhar, e será reunida, a partir de 1987, num volume com o título geral $O$ medo. Entretanto produzira-se a cisão do nome e, com ela, o nascimento de $\mathrm{Al}$ Berto.

3 Todas as imagens referidas ao longo do texto estão nos anexos.

Remate de Males, Campinas-SP, v.39, n.1, pp. 191-218, jan./jun. 2019 - 192 
de disciplina artística nem é atribuível ao tempo de execução que supostamente seria mais breve na escrita: é apenas uma implicação do ser-se humano num mundo em que o humano é sempre incidental (ao contrário dos seus efeitos, dir-se-ia), e o mesmo para as suas epifanias. Abandonar a pintura porque ela leva muito tempo a executar é uma justificação tão pouco satisfatória como qualquer outra, uma abonação de boa consciência para quem não consegue reter o coração sangrento das coisas, ou o esplendor da noite, assim que se desloca para o território da representação (ou, como diria um outro escritor português, Carlos de Oliveira, assim que passa do respirar ao escrever). Isto é, todos nós, pintores, escritores ou não.

Existe, como sabemos, toda uma filogénese das palavras de Beno, que nos chegam por Alba, sobre o tempo de execução, ou melhor, sobre a infinita duração do hiato entre a realidade do momento e a representação (faço notar que a duração do hiato é sempre infinita, ainda que infinitesimal, em relação à realidade do momento). E é certo que o século XX, desde as vanguardas históricas, se esforçou por reduzir esse hiato, quer pela produção de novas versões ou disciplinas da expressão artística (a action painting, a art brut, a performance, o cinema direto, a escrita automática etc.), quer pelos contributos da evolução tecnológica no que toca à redução da duração desse hiato (a câmara portátil Portapak e depois a câmara digital, de fotografia ou vídeo, a máquina de escrever e depois o computador, a caneta de tinta permanente e, hoje, a rollerball etc.). Mas não creio que a questão das materialidades da comunicação seja aqui fundamental, ou mesmo pertinente, pois convém lembrar que as palavras de Alba surgem depois das palavras de Beno, nas quais a escrita não parece ser garantia de um acercamento mais súbito ao coração das coisas. Recordo essas palavras:

\footnotetext{
Não temos saído daqui, como sabes - explicou Beno. - Ando a ver se termino este livro. Está a tornar-se uma doença, avança tão lentamente que, se calhar, ainda morro antes de escrever a palavra fim. E depois, é mais importante para mim... não sei, já não sei. Deixei de pintar e, agora, se deixasse de escrever, era mesmo o fim. O fim de tudo (AL BERTO, 1999, p. 85).
}

Para quem teria abandonado a pintura por esta não lhe permitir “explodir a cada segundo", essas palavras são tão melancólicas quanto esclarecedoras, nas suas vastas ressonâncias, quase todas em torno da palavra fim. Deixar de escrever seria o fim de tudo; mas uma escrita que se arrasta sem fim à vista (e essa seria uma possível definição de escrita: uma 
prática sem fim à vista) é uma patologia que promete a morte. O problema, então, e em rigor, não estaria nem na pintura nem na escrita, mas no projeto de uma forma de vida que permitisse ao seu cultor "explodir a cada segundo". Mas de que modo é que uma tal forma de vida poderia ser ainda uma forma de expressão partilhável? Notemos que uma arte animada por um tal projeto teria de desconhecer as noções de começo e fim, restando-lhe uma pura intensidade sem história (uma coisa entre o orgasmo e o chuto). As palavras de Alba são, a esse respeito, fundamentais: "Lembras-te? estavas sempre a dizer coisas destas, ninguém sabia se falavas a sério ou deliravas". O drama a que essas palavras dão voz é muito reconhecível num largo segmento do século XX, e podemos designá-lo como o drama da contracultura, incapaz de sustentar uma prática representacional à altura de um projeto de intensificação da experiência e, mais ainda, de alucinação do real: como explodir a cada segundo, mas, sobretudo, como exprimir e representar essa explosão que, paradoxalmente, deveria viver num recomeço perpétuo? E, antes ou depois disso, de que modo é que uma forma de vida (como esta, mas não necessariamente apenas esta) é arte?

Lunário explora esse problema na terrível cena de crueldade que é a performance com que Beno se despede do mundo da arte, ou melhor, dos compromissos com a sua galeria. Vale a pena transcrever a descrição da performance que Beno, coadjuvado por Kid (alguém que não sobreviverá ao projeto de "explodir a cada segundo"), encena:

Suspenderam uma barra de ferro do teto, e amarraram-lhe um animal vivo pelas patas. $\mathrm{O}$ animal estrebuchou, de barriga para cima, o pelo eriçado, pendurado sob a luz cegante do holofote.

...

A tensão crescia entre o público: ouviam-se vozes, alguém tossicava nervosamente. Beno abriu a mão, estendendo o braço para fora do círculo de luz, e Kid passou-lhe uma vara de ferro aguçada em ambas as pontas. Beno rodeou o animal, e num gesto lento, preciso, enfiou-lhe a vara de ferro no ânus, empalando-o.

$\mathrm{O}$ animal contraiu-se, ficou palpitante um segundo antes de se distender e sossegar (AL BERTO, 1999, p. 79).

Se bem vejo, não se trata de propor esse exercício de crueldade como Arte, mas sim de interrogar o ponto de articulação, a dobradiça, a dobra por meio da qual uma forma de vida, mesmo que chocante, pode, ou não, ser socialmente redistribuída como forma de expressão. Nenhum outro momento em Lunário exemplifica melhor as aporias do projeto de "sentir 
o coração das coisas a sangrar, ou explodir a cada segundo", já que, no final do empalamento, o "sossego" do animal assassinado, a sua paz, tem como contraface a descrição da alucinação de Beno:

Beno esbugalhou os olhos e respirou fundo. O suor escorria-lhe por todo o corpo, sentia-se pegajoso, e tinha as calças, a camisa e os pés sujos de sangue coalhado. Kid agarrava-lhe no braço, amparando-o, enquanto caminhavam (AL BERTO, 1999, p. 80).

Não existe consenso social, obviamente, para uma cena dessas, que também parece carecer de descrição, se excetuarmos a estratégia que Lunário ativa e que consiste basicamente em transpor a gramática do sacrifício ritual e do êxtase para essa performance (uma prática que por aquela altura, anos 1960-1970, entre performance e Body Art, começa a adquirir uma gramática, mesmo para exemplos desse teor, aliás não raros então). Mas sobretudo não parece possível fazer dessa performance o modelo de uma forma de vida, perto do coração sangrento das coisas: e talvez por isso, ao sair dela, Beno necessite do apoio e amparo de Kid para que esse êxtase sujo, algures entre o orgasmo e o sangue, ou entre o ritual e o crime, não lhe retire o chão de debaixo dos pés - ou então que lhe retire apenas o tempo indispensável à oscilação ontológica de um real em fuga.

\section{II}

Permitam-me que regresse às palavras de Beno sobre a escrita, para passarmos ao tópico seguinte: "Não temos saído daqui, como sabes explicou Beno. - Ando a ver se termino este livro". Não se trata, pois, de escrever, apenas, ou de trocar a pintura pela escrita, mas sim de escrever um livro. E esse é o ponto em que podemos regressar, de Lunário, a Projets 69, obra que, para pôr as cartas na mesa, gostaria de trabalhar a partir daqui como um Livro de Artista. Que se trata de uma publicação é o que nos diz a indicação seguinte, na contracapa: "responsable de la publication joelle de la casinière”. ${ }^{4}$ Devo dizer que é a única indicação de que dispomos nesse sentido, já que a rarefação de informação é de ordem, naquilo que envolve este livro de Alberto Tavares: o primeiro livro de Alberto Tavares, ou melhor, o livro de Alberto Tavares, já que não houve um segundo, e, por isso mesmo, um livro que cabe mal na indicação "obras de Al Berto" que surge no verso da capa da edição Assírio \& Alvim. Dizer que cabe mal

4 [...] responsável pela publicação joelle de la casinière.

Remate de Males, Campinas-SP, v.39, n.1, pp. 191-218, jan./jun. 2019 - 195 
nessa indicação não é o mesmo que dizer que não cabe de todo, tanto mais que existe um livro de $\mathrm{Al}$ Berto que dialoga proximamente com Projets 69: refiro-me, é bom de ver, a Lunário.

O Livro de Artista, lembra Johanna Drucker (2004, p. 2, tradução minha), em The Century of Artist's Books, "é um livro criado como uma obra de arte original, e não como uma reprodução de uma obra pré-existente ${ }^{5}$. E é também um livro que integra nos meios formais da sua realização e produção questões temáticas e estéticas". Isso significa que o Livro de Artista "é quase sempre autoconsciente em relação à estrutura e ao significado do livro enquanto forma” (p. 4). Um meio típico do século XX, o Livro de Artista não ganha em ser definido por critérios muito estreitos e literais (como tende a ocorrer na escola francesa de Anne Moeglin-Delcroix, muito empenhada em produzir critérios de exclusão), já que aquilo que o define é que ele pode tomar todas as formas possíveis, desde que a própria ideia de forma do livro seja objeto da sua atenção crítica e metacrítica. Nas palavras de Drucker, o que está em causa no Livro de Artista é produzir "termos críticos com os quais examinar o teor livresco do livro, a sua identidade como um conjunto de funções estéticas, operações culturais, conceções formais e espaços metafísicos” (p. 9). Ou seja, o Livro de Artista é muito mais uma "zona de atividade", expressão muito do agrado de Drucker, feita da interseção de muitas disciplinas, campos e ideias, do que uma categoria fixa.

Projets 69 situa-se entre duas imagens que o abrem e fecham: a primeira dá-nos o começo do livro (Figura 3), enquanto a última nos dá o fecho (Figura 4). O espaço do códex fica assim delimitado perfeitamente nos extremos da sua sintaxe e, ao mesmo tempo, é-nos dada uma lição prática de técnicas de impressão, entre a sugestão serigráfica da primeira e a xerográfica da última, próxima da Copy Art, que se manifesta noutras imagens do livro. Por outro lado, e decisivamente, a página inicial, que seria a 2 (a página par, a página má dos designers), dá início à cerimónia, ou ao espetáculo - START - por meio de uma imagem do autor sentado, olhando para o leitor de perfil, ${ }^{6}$ com uns óculos de sol Ray Ban. Essa imagem desencadeia uma série de efeitos sintáticos na progressão da leitura. Por

\footnotetext{
5 It's easy enough to state that an artist's book is a book created as an original work of art, rather than a reproduction of a pre-existing work. And also, that it is a book which integrates the formal means of its realization and production with its thematic or aesthetic issues.

6 A ficha técnica de $O$ medo informa: "Na capa: Retrato de Al Berto encenado por Paulo Nozolino em homenagem a Caravaggio" (AL BERTO, 2017, contracapa). A colaboração 
um lado, articula-se com a página seguinte, RAY BAN ACTION (Figura 5), que propõe o guião ou partitura de uma performance em parte descrita na anterior imagem do autor: o autor sentado limpa uns óculos de sol Ray Ban durante cerca de 20 minutos. O título exprime toda a ambiguidade da contracultura em relação a uma ideia de ativismo politicamente direcionado, na medida em que propõe, ao mesmo tempo, banir a ação (BAN ACTION), recuperando toda a mística do dandy oitocentista. A imagem concilia o desenho dos óculos, ao fundo, com o guião, logo acima, uma espécie de formulário com as instruções para a performance, cujo teor repetitivo e monótono é visível (legível) nas indicações textuais da ação que se repete, nesse bloco central da página, após as indicações de cena e duração, logo abaixo do título, este em caixa alta e negrito. Por outro lado, e muito brevemente, a imagem START inicia uma série de trabalhos em torno do autorretrato, que no livro ocupam cinco páginas (e que será um dos tópicos recorrentes do trabalho do $\mathrm{Al}$ Berto poeta, que tenderá a autorrepresentar-se na própria capa dos livros e, desde logo, como vimos, na capa da coletânea da sua poesia, $O$ medo (Figuras 6 a 9).

Mas de certo modo a ambiguidade deste título repercute em todo o livro, que proporá formas de ação que, por radicalmente estéticas, parecem supor uma atitude irónica em relação à própria ideia ativista que o livro, contudo, também transporta, desde a capa e em várias outras ocorrências que o inscrevem num ativismo gay tão historicamente sintonizado quanto, como sempre em Al Berto, radicalmente "naturalizado". Mais importante, porém, é que esta primeira partitura dá o tom a todo o livro, que no essencial oscila entre dois média muito produtivos nos anos 1960 e 1970, a performance e a instalação. O título, Projets 69, não é uma variação daquela prática, frequente na pintura, da obra "Sem título". Pelo contrário, é um título muito descritivo, ${ }^{7}$ que nos dá uma versão do livro como Manual de Instruções, ou seja, como aquele tipo de livro que pressupõe a todo instante a saída para fora de si, para esse espaço exterior no qual deveremos imaginar as performances e instalações que imagens e textos desencadeiam. São projetos desenhados e descritos em instruções e legendas (e daí a pertinência do preto e branco, típica opção de projetista)

entre Al Berto e Paulo Nozolino, importante fotógrafo português, foi longa, manifestandose nas capas de vários dos seus livros por meio de fotos do autor.

7 Mas também, obviamente, irónico, já que a datação pressupõe uma brincadeira erótica com o ano eleito, 69, que lembra o modelo de título de uma famosa canção de Serge Gainsbourg com Jane Birkin: “69, année érotique”. 
que nos dizem como fazer. Mas essa versão performativa do livro sofre a sobreposição de uma série de efeitos concetuais, mais nítidos, por exemplo, em todo o cromatismo que a obra solicita, fazendo-o, porém, na linguagem do preto e branco e exigindo, por isso, que o leitor imagine ativamente esses efeitos cromáticos, básicos e intensos, que os projetos propõem. Indicar, a preto e branco, uma paleta cromática "violenta", é algo que reintroduz na obra o hiato da representação, neste caso entre referente e signo convencionado.

Na sintaxe do livro, após a apresentação do autor e a declaração metapolítica implícita em RAY BAN ACTION, progride-se pelo interior da casa, começando na sala (Figura 10) e avançando para o jardim (Figura 11). A cultura objetiva do mundo capitalista triunfa por todo lado, em The Living Room, na forma de candeeiros (ou melhor, tubos com lâmpadas na extremidade), escovas dentífricas, escovas de limpeza, chupetas, balões, muito plástico, e tudo isso sobre relvado artificial e cores básicas: rosa, verde, amarelo, preto. Algo da mesma ordem ocorre em The Garden.

Passa-se depois progressivamente para fora da casa (Figura 12), começando por um carro cor-de-rosa com a superfície cheia de escovas dentífricas de todas as cores e contendo no interior uma paisagem artificial e uma televisão. O carro tem ainda a particularidade de distribuir um panfleto por onde passa. A seguir (Figura 13) uma fonte "a colocar em grandes relvados verdes", que representa um telefone que jorra pasta dentífrica, feito de matéria plástica negra, vermelha e amarela. E com uma campainha que desencadeia a mudança de cor da água que jorra dos tubos de pasta dentífrica. Ou a grande "caixa sexo prenda" (Figura 14), a colocar em cruzamentos, como muitas dessas obras, com um sistema no interior para ativar um produto rosa, que jorra do pénis e se espalha por todo lado. Ou ainda, e voltamos à performance, os amendoins colantes (Figura 15), pintados em "cores violentas" e embebidos em cola que se espalham previamente numa rua, numa camada de $50 \mathrm{~cm}$, de modo a que se colem às calças, sapatos etc., de quem passa. E há ainda instalações com um líquido semelhante a iogurte, que se espalha por um cruzamento, ao mesmo tempo em que se ouve um discurso sobre o esperma; ou uma praça que se bloqueia com grandes blocos de gelo coloridos, tendo a circulação automóvel de esperar que derretam etc.

Voltarei a essas imagens, mas quero concluir o elenco com outras duas que se me afiguram fundamentais. Na primeira (Figura 16) dois prédios lado a lado, uma foto do inquilino e dois grandes tubos que incham e 
desincham e ligam os dois prédios, ouvindo-se o sopro da respiração. Na segunda (Figura 17), intitulada "Promenade dans la mer", um grande tubo submerso permite passeios no mar.

Toda essa imagética, bem como os materiais em que se apoia (desde logo, o plástico), é reconhecível na fase inicial da escrita de Al Berto, editada entre 1977 e 1981 em edições de autor (Alberto R. Pidwell Tavares, Editor), ainda antes da cisão do nome, de que resultará esse nome "demasiado produzido", Al Berto. ${ }^{8}$ Por exemplo, em Meu fruto de morder, todas as horas (1978/1979):

[...] tudo respira pelos órgãos de vinil. enxertados os órgãos voltam a crescer com outras formas, metamorfoseando-se com as fases da lua. um coração enxertado na pele tatuada dum marinheiro bate como um mar. alarme dos subterrâneos inacessíveis. cada um morre como pode, sozinho. morre-se sempre sozinho. e de pólo a pólo estende-se um tubo central onde nós somos os dejectos a delinquência o veneno o lixo os gases as substâncias inquinadas (AL BERTO, 2009, p. 124).

\section{Ou em Quinta de Santa Catarina (AL BERTO, 1979, p. 132):}

[...] animais estrangulados, matérias plásticas, um tijolo com os furos cheios de avencas.

Ou seja, existe uma notória coerência entre os trabalhos reunidos em Projets 69, o trabalho gráfico desenvolvido por Alberto Tavares nos livros e materiais promocionais da sua editora nos anos 1970, a sua escrita inicial, desregrada, ou seja, percorrendo sem cessar todo o território entre prosa e poesia, entre autobiografia e ficção, ou melhor, entre auto / bio / e grafia, enfim, tudo isso que Lunário, no final dos anos 1980, quando o nome Al Berto se estabiliza como "nome de poeta", revisita e aparentemente encerra. Mas a edição póstuma de Projets 69 vem evidenciar a que ponto essa tentativa de encerramento é infrutífera, já que da articulação entre essa obra e Lunário resulta a reativação de toda essa fase inicial de sobreposição, mais do que transição, entre produção plástica e produção escrita. Essa fase que pede hoje uma releitura crítica menos submetida à canonização posterior de Al Berto do que disponível para reavaliar a intensidade experiencial e imagética de uma prática de transgressão ou desdobramento sistemático de fronteiras e géneros.

8 Sobre a questão do nome em Al Berto, é fundamental ler o capítulo “Ce(n)sura” do livro de Golgona Anghel (2013, pp. 89-115) sobre o poeta. 


\section{III}

Regressando a Projets 69 e resumindo: plástico, balões, relva artificial, líquidos coloridos semelhando iogurte ou esperma, blocos de gelo, pasta dentífrica, cola - e ainda tubos, ligações, um exobrônquio e um exointestino que religam o mundo, colocando no mesmo plano o humano, a natureza e o mundo construído. Como não pensar na leitura de Al Berto por Golgona Anghel (2008, p. 29). Essa leitura radicalmente deleuziana, que nos fala da "perceção da imanência, a perceção de todas as coisas (das que existem e das que nunca chegaram a ser) como inscritas numa matéria única, num único plano, o plano da univocidade do ser". ${ }^{9}$ E disso que trata também Projets 69, na sua imagética pop, na sua política situacionista comandada pela máxima RAY BAN ACTION e, como sempre em Al Berto, cedendo o indispensável ao kitsch do cromatismo Robbialac ou do rococó de uma capa em que os sexos dos anjos esvoaçam em fundo dourado. Como aqueles anjos de Lunário, de nome Lúcio e Gazel, que, ante a perplexidade e deslumbramento de Beno, que os acompanha, invadem mansões burguesas para nada roubar:

- Não somos ladrões. A única coisa que nos dá gozo é foder nas camas dos outros. Deixar sinais, percebes? Porque deve ser inquietante, quando regressam, descobrirem que alguém esteve ali, a foder... percebes? Só isso, sobretudo deve ser intrigante quando veem que não lhes falta nada ( $\mathrm{AL}$ BERTO, 1999, p. 30).

Talvez pudéssemos, por fim, articular esta performance situacionista (que seria interessante aproximar do comportamento da personagem de Kim Ki-Duk que, em Ferro 3, assalta casas para também nada roubar, limitando-se a alimentar-se do frigorífico e aproveitando até para consertar coisas avariadas), com a instalação em que Nému transforma o quarto:

Fora por essa altura que Nému começara a cobrir as paredes do quarto com imagens laboriosamente recortadas das revistas. E colocara também, e de tal modo, os poucos objetos existentes na casa em lugares inesperados, que estes logo adquiriam novas formas de existência. Cada objeto surgia como que votado à sua enorme solidão, isolado do mundo, diferente e separado de todos os seus semelhantes.

9 Reporto-me aqui à tese de doutoramento de Golgona Anghel sobre Al Berto, provavelmente o ponto mais alto da leitura da obra do poeta. Dessa tese viria a ser editado um livro (Cronos decide morrer, 2013) que cito antes) e que, contudo, não a transcreve na totalidade; daí o facto de sentir a necessidade de me reportar a ela neste ponto. 
As imagens recortadas começaram a subir pelas paredes acima, até ao teto. Forraram-no por completo, e depois desceram, atapetando grande parte do soalho.

Nému mudava-as de sítio, ordenava-as, numa incessante procura de sentidos. Organizava-as a partir duma memória de mundos antigos e caóticos e assim, diariamente, surgiam nas paredes restos duma vida anterior ao seu encontro com Beno. Dispunha-as com precisão, arrumadas de tal maneira que as paredes se transformavam em extensos calendários, ou num rigoroso diário. Pacientemente, com a minúcia do relojoeiro, Nému descobrira como tornar visível a sua paixão por Beno (AL BERTO, 1999, p. 62).

A frase-chave é aquela em que se diz que Nému descobrira como tornar visível a sua paixão por Beno. Pois tornar visível a paixão é um projeto que podemos aproximar daquele outro projeto de Beno, também por volta de 1969, de sentir o coração das coisas a sangrar e dar-lhe forma. Por outro lado, e decisivamente, ao dispor as imagens no quarto, Nému parece articular o site-specific com a genealogia, e com a genologia de dois grandes modelos, o calendário e, sobretudo, o diário: "Dispunha-as com precisão, arrumadas de tal maneira que as paredes se transformavam em extensos calendários, ou num rigoroso diário". Calendário e diário são modalidades de inscrição do tempo, mas, no último caso, modalidades ainda de livro (o quarto de Némur, a disposição das fotos pelas paredes e pelo chão, seriam assim o seu livro - de artista). Daí o facto de as imagens se irem desvanecendo, após a partida de Nému:

Quando voltara a casa pusera-se a olhar para as fotografias que Némur espalhara pelas paredes. Tinham-se tornado confusas, encarquilhadas pela humidade, desbotadas - e ele não dera por isso. As imagens mal se percebiam, tinham emudecido, abandonadas à luz que as degradara (AL BERTO, 1999, p. 152).

A partir desse momento, o projeto de “tornar visível a paixão" já só pode exibir destroços:

Também havia peças de roupa espalhadas pelo quarto, como destroços de uma paixão ainda presente e já tão remota.

Beno guardara a roupa numa gaveta e arrancara as fotografias das paredes. Estava só, definitivamente só. Quase sufocava. Descera as escadas a correr e saíra para a rua (AL BERTO, 1999, p. 153).

Proponho que se leia este "quase sufoco" como momento simétrico da tontura que toma Beno após o sacrifício ritual do animal na performance. Excesso e carência, proximidade perigosa, porque não mediada pela 
representação, do "coração a sangrar das coisas", luto pela imagem enquanto projeto de vida, enfim, confronto insuportável com a vida nua.

\section{$\overline{\text { REFERÊNCIAS }}$}

AL BERTO. Lunário. 2. ed. Lisboa: Assírio \& Alvim, 1999.

AL BERTO. Projectos 69, Lisboa: Assírio \& Alvim, 2002.

AL BERTO. O medo. Lisboa: Assírio \& Alvim, 2017.

ANGHEL, Golgona. A metafísica do medo. Leituras da obra de Al Berto. Tese (Doutorado em Estudos de Literatura e de Cultura) - Estudos Portugueses, Universidade de Lisboa. Lisboa, 2008. Disponível em: <http://hdl.handle.net/10451/542 >. Acesso em: 14 maio 2019.

ANGHEL, Golgona . Cronos decide morrer. Lisboa: Língua Morta, 2013.

DRUCKER, Johanna. The Century of Artist's Books. New York: Granary Books, 2004. 


\section{ANEXOS}

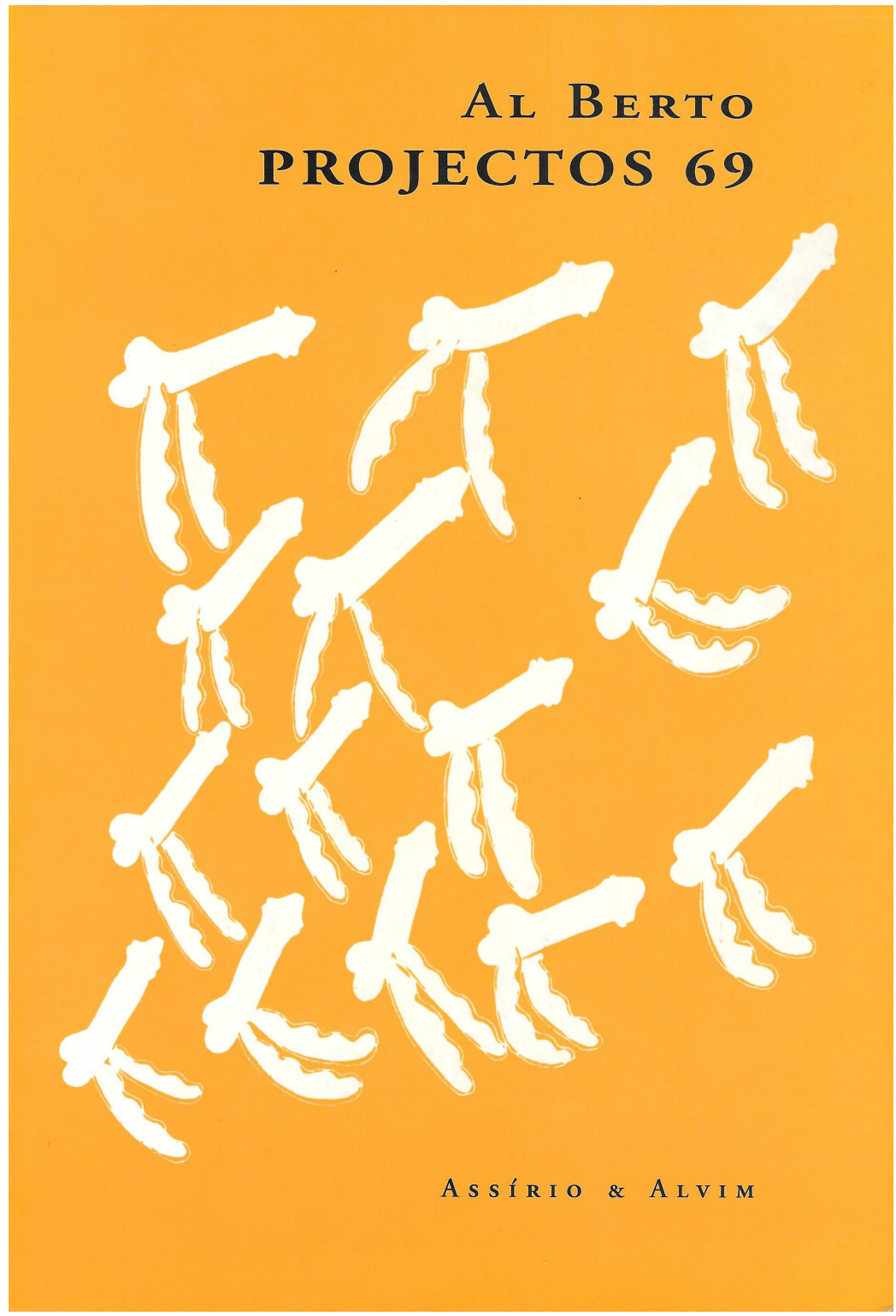

Figura 1. Capa da edição Assírio \& Alvim, de Projets 69 (AL BERTO, 2002). Fonte: Fotografia do exemplar do autor. 
ALBERTO TAVARES ALBERTO TAVARES ALBERTO TAVARES ALBERTO TAVARES ALBE PROJETS 69 PROJETS 69 FROJETS 09 PROJETS 69 PROJETS 69 PROJETS 69 PR ALBERTO TAVARES ALBERTO TAVARES ALBERTO TAVARES ALBERTO TAVARES ALBE PROJETS 69 PROJETS 69 PROJERS 69 PROJETS 69 PROJETS 69 PROJETS 69 P alberto tavarea projets 69 alberto tauares projets 69 atberto tavare ALBERTO TAVARES ALBERTO TAVARES ALBERTO TAVARES ALBERTO TAVARES ALBE PROJETS 69 PROJETS 69 IROJETS 69 PROJETS 69 PROJETS 69 PROJETS 69 PR ALBERTO TAVARES ALBERTO TAVARES ALBERTO TAVARES ALBERTO TAVARES ALBE PROJETS 69 PROJETS 69 PROJETS 69 PROJETS 69 PROJETS 69 PROJETS 69 PR

Figura 2. Bloco textual Projets 69 (AL BERTO, 2002).

Fonte: Fotografia do exemplar do autor. 


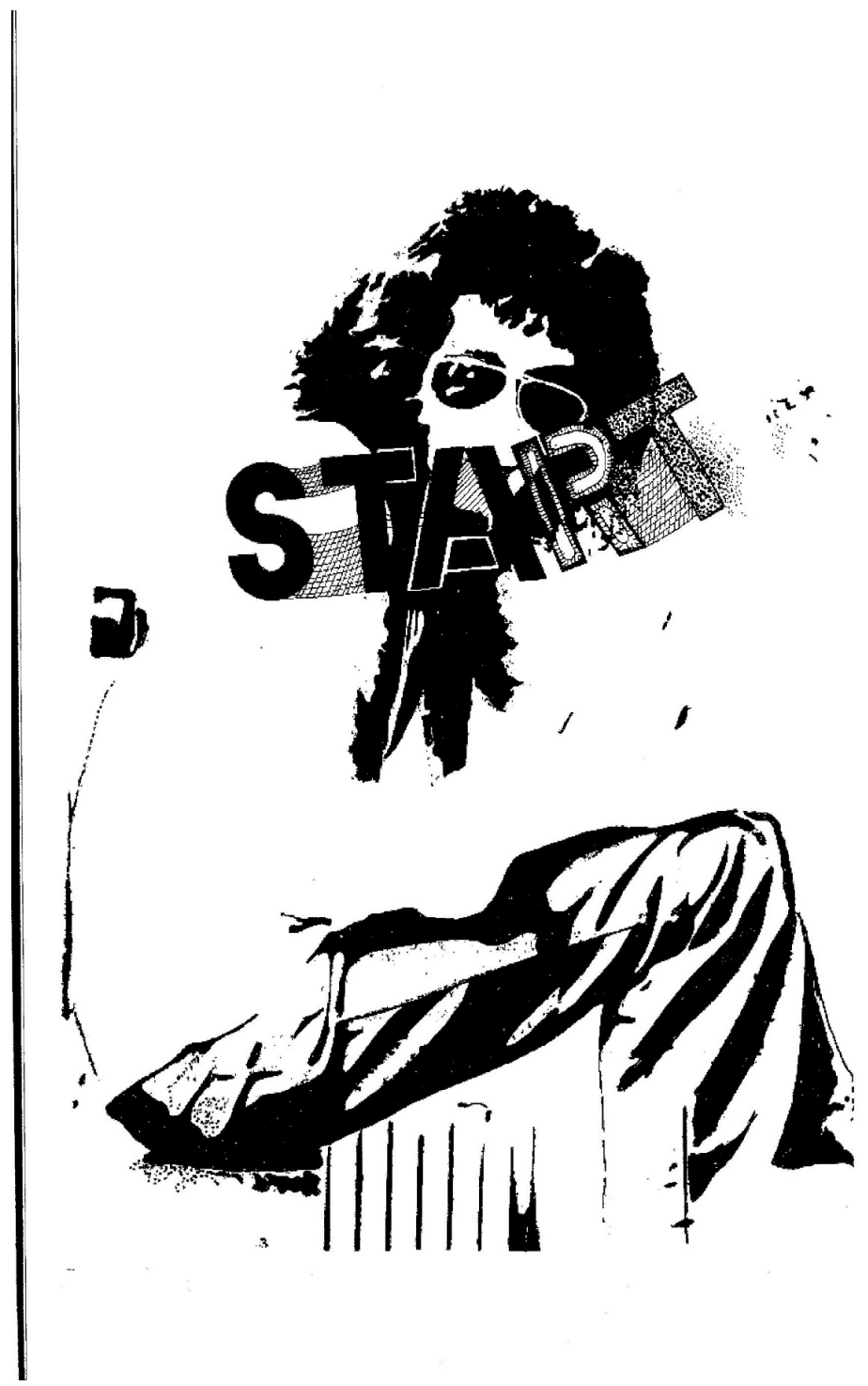

Figura 3. Imagem do livro Projets 69 (AL BERTO, 2002). Fonte: Fotografia do exemplar do autor. 


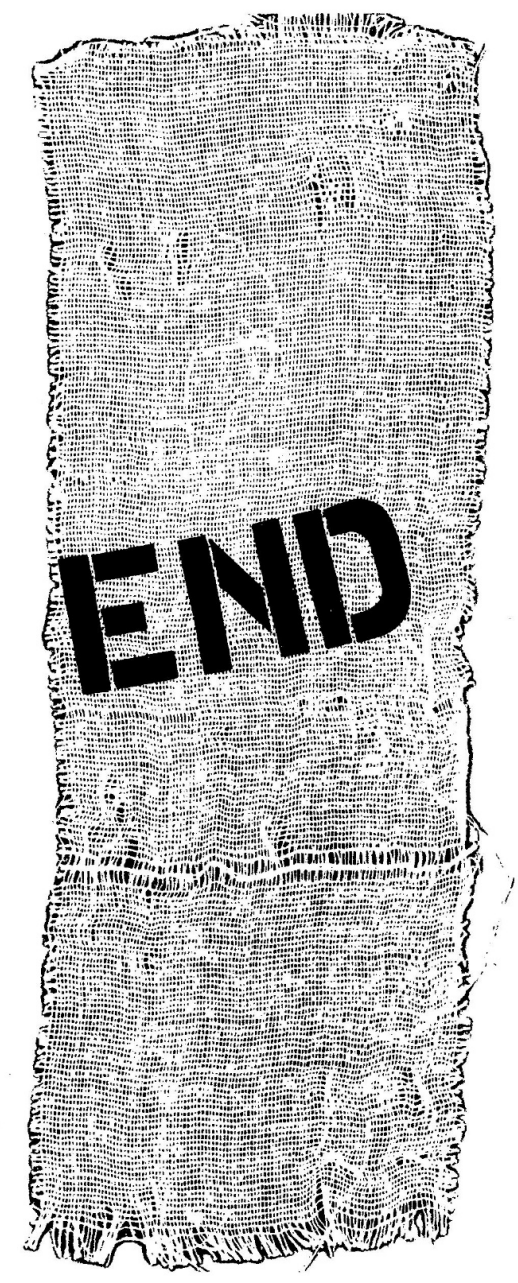

Figura 4. Última imagem de Projets 69 (AL BERTO, 2002).

Fonte: Fotografia do exemplar do autor. 


\section{RAY BAN * ACTION}

DUREE.....20 mintstes

ENDBOTT... Sable quelconque blanche vise

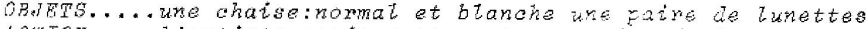
ACrION.... L aptiste assis nettoyart wna paine de lunetbes ray ban

ININUTE/L'ARTISTE ASSTS NETTOYANT UNE PATRE DE LUWETTES RAY BAM

EUINUTE/L'ARTISTE ASSIS NETTOYANT UNE PAIRE DE IUHETTES RAY BAN 3WINUTE/L'ARTISTE ASSIS NETTOYANT UNE PATRE DE LUNETIES RAY BAVE 4WINUTE/L'ARTISTE ASSTS NETTOYANT UNE PAIRE DE LUMETIES RAY BAM EMINWE/L ARTISTE ASSIS NETTOYANT UNE P/IPE UF DUNETPES RAY BAR OWINUTE/L 'ARTISTE ASSTS NETTOYANT UNE PAIRE DW WUNETTES RAY BERE TMINUTE/L'ARTISTE ASSIS NETTOYANT UNE PATRR DE LUNETTES RAY BANS ZWIWUTE/L'ARTISTE ASSIS NETTOYAII WNE PATES DE IUNETTES RAY BAX OWTWUELI'ARTISTE ASSIS NETTOYAWT UNE PAIRE DE LUNETTES PAY BAT IONIWUTE/L'ARTISTE ASSTS VETTOYAWT UNE FAIRE DE LUNETTES FAY BA 11 MNUTE/D'ARTISTE ASSTS NETTOYANT UNE PAIRE DE LUNETTES RAY BANF I2MINUTE/L'ARTTSTE ASSIS NETMOYANT UNE PATRE DE LUNETTES RAY BANY IJMNUTE/L'ARTISTE ASSIS NETTOYANT UNE TATRE DE LUNETTES RAY BAN

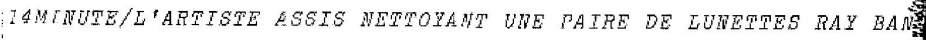
ISMTWUTE/L'ARTISTE ASETS UEWWOYANT UNE PATRE DE LUNETTES RAY BAVT

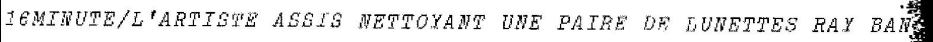
ITMIWUTE/L TARTSSE ASSTS NETTOYANT UHE PAIPE DE LUNETTES RAY BAW I8MUUTE/L 'ARTISTE ASSTS NETTOYANT UNE PATEE DE IUNETTES RAY BAN I GWINUTE/E 'ARTISTE ASSTS NETTOYANT UNE PATRE DE IUWETTES RAY BAM 2OHIDUTE/L'ARTISTE SE LEVE ET SORT DE LA SALLE NEWOYAMT TOUWOURS

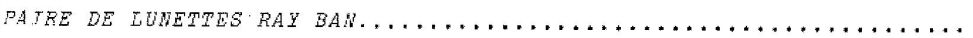

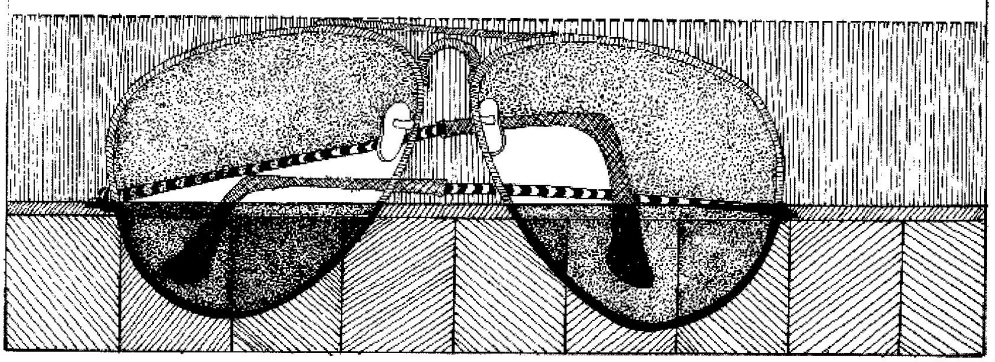

Figura 5. Projets 69 (AL BERTO, 2002).

Fonte: Fotografia do exemplar do autor. 


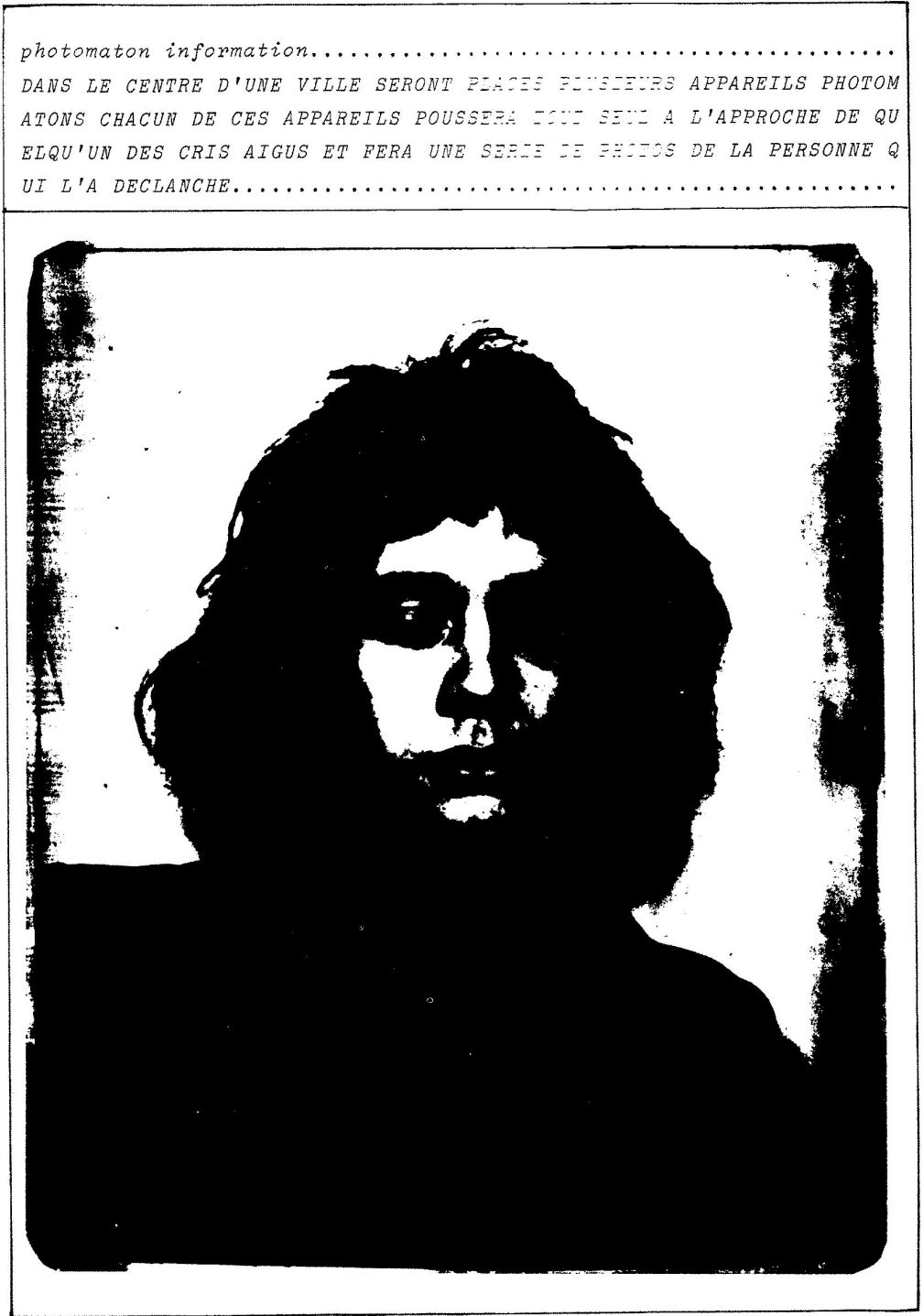

Figura 6.

Fonte: Fotografia do exemplar do autor. 


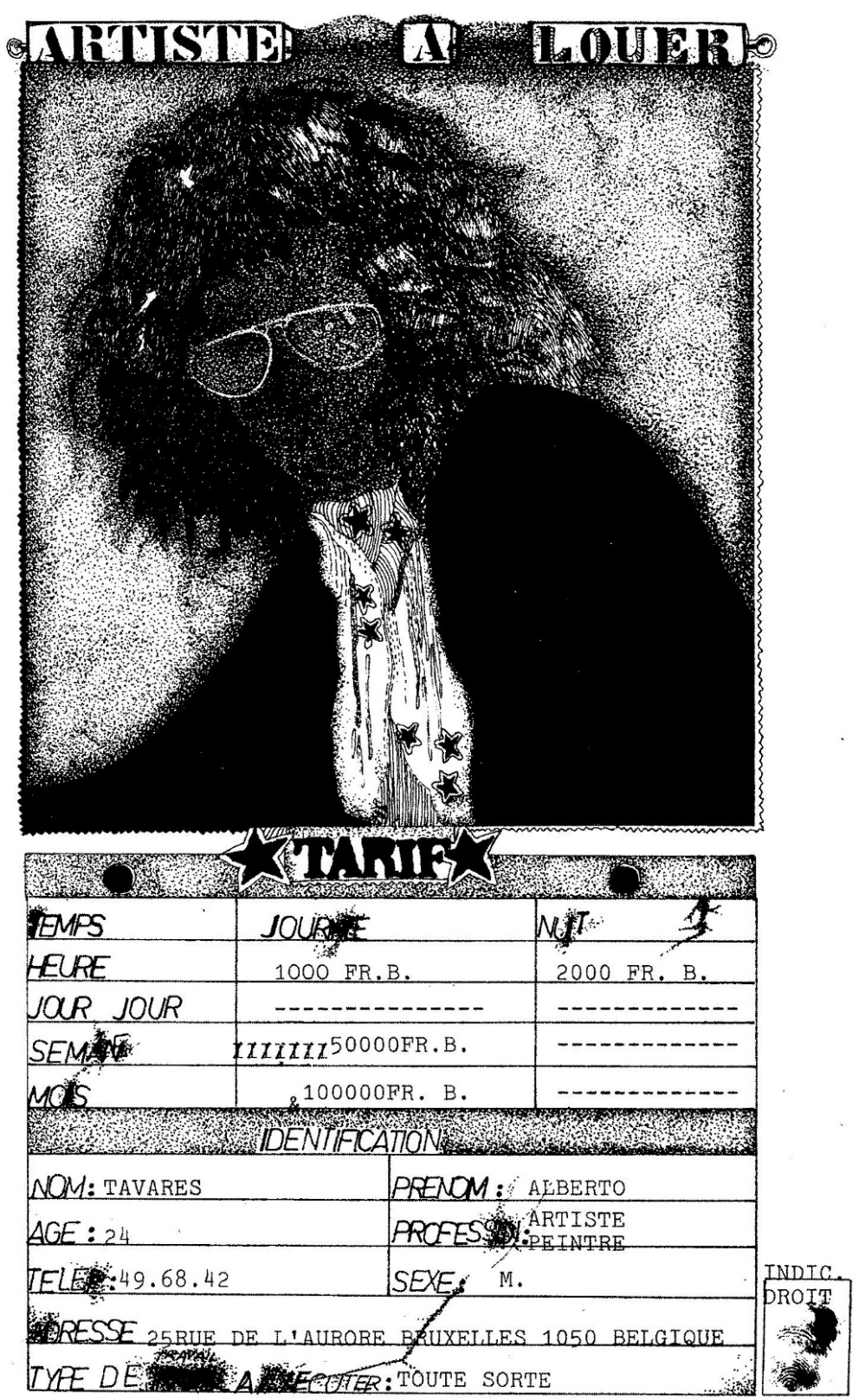

Figura 7.

Fonte: Fotografia do exemplar do autor. 


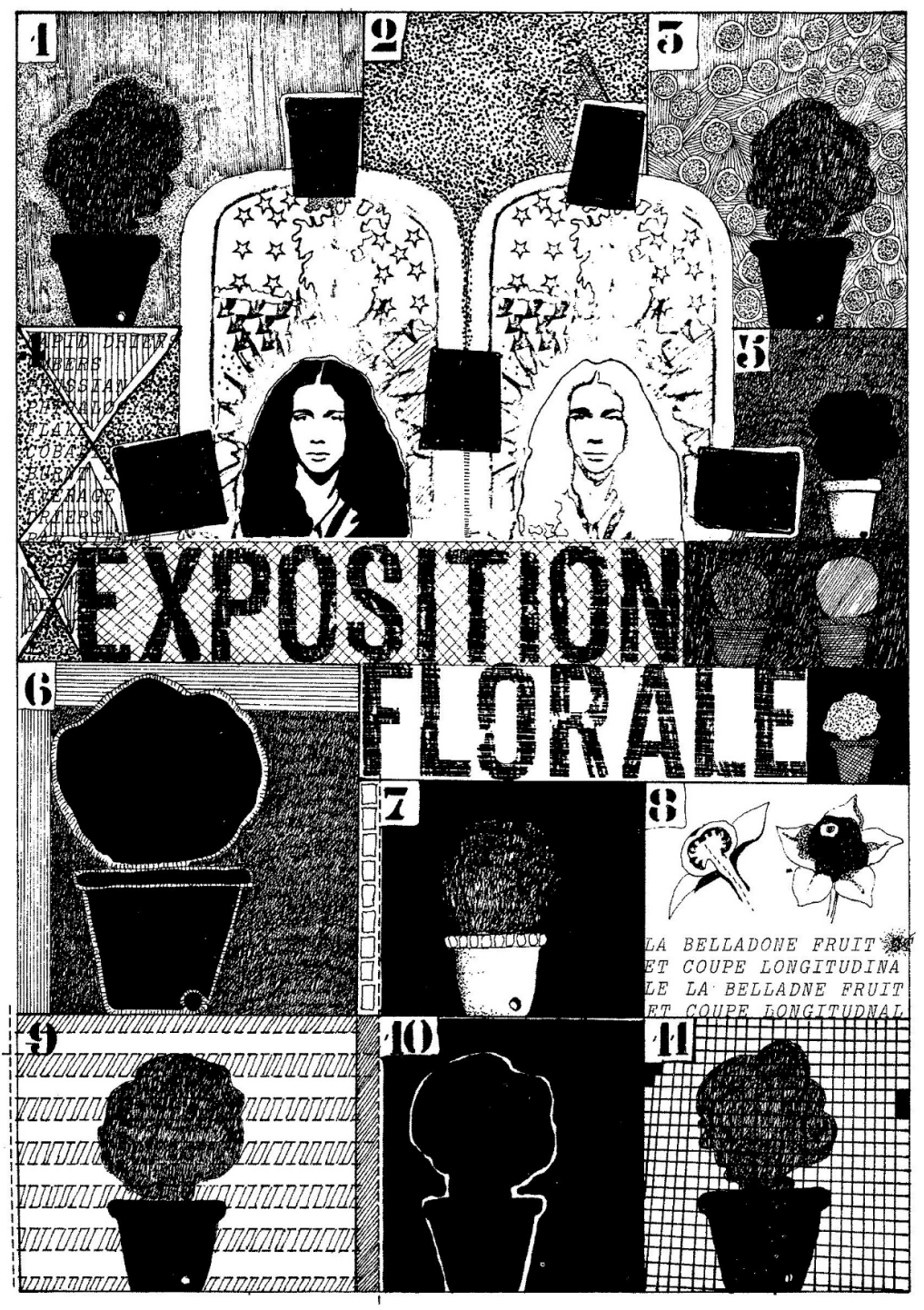

Figura 8.

Fonte: Fotografia do exemplar do autor. 


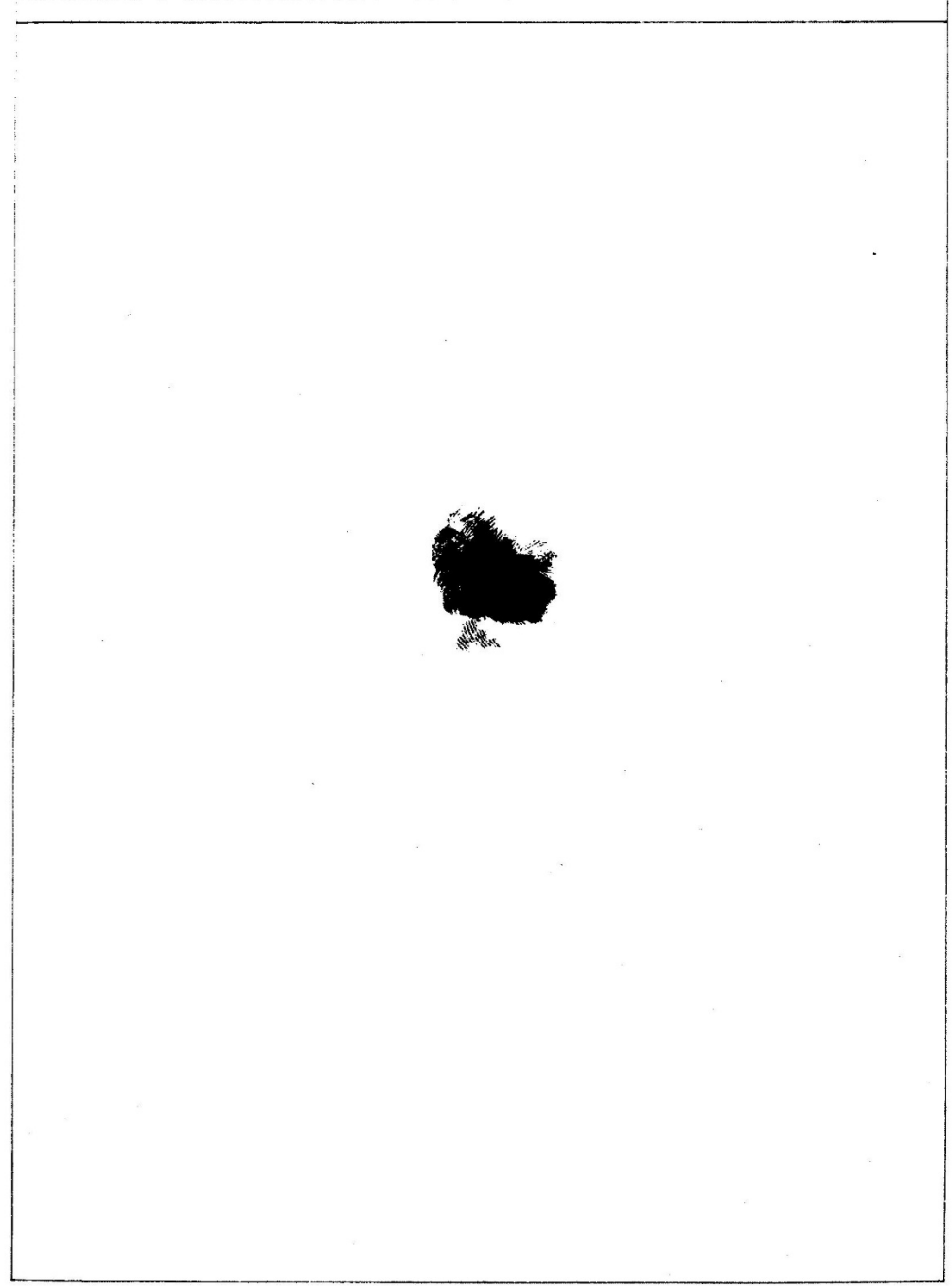

Figura 9.

Fonte: Fotografia do exemplar do autor. 


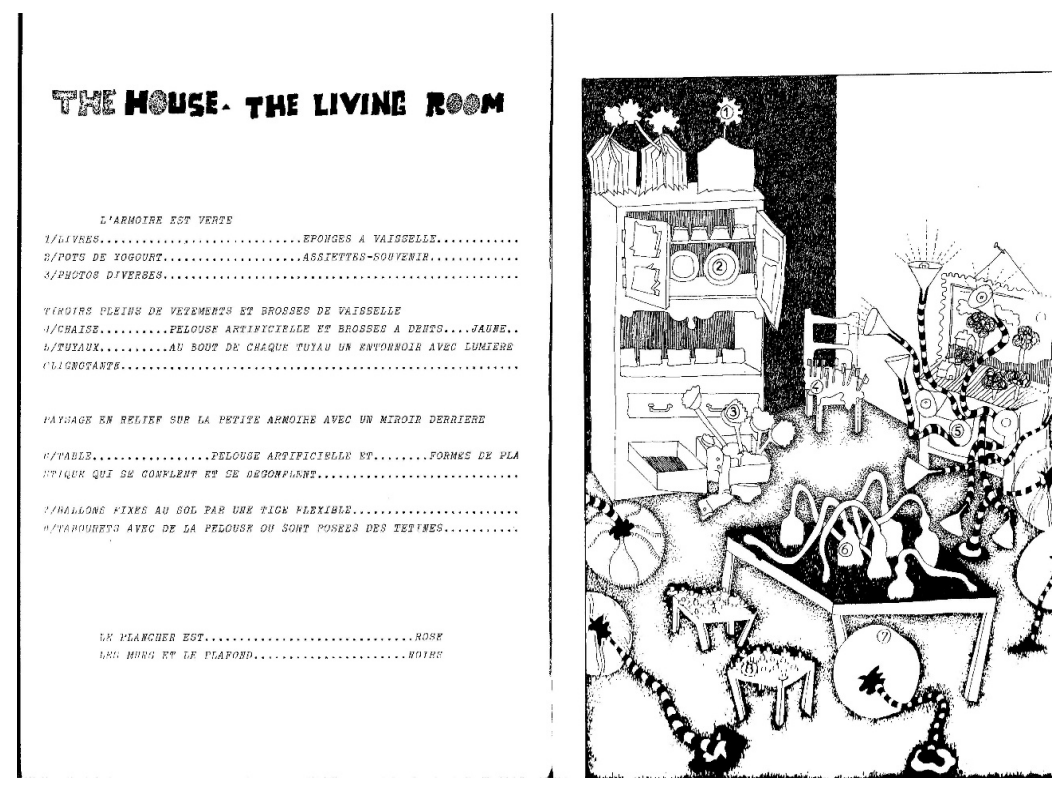

Figura 10. Projets 69 (AL BERTO, 2002).

Fonte: Fotografia do exemplar do autor.

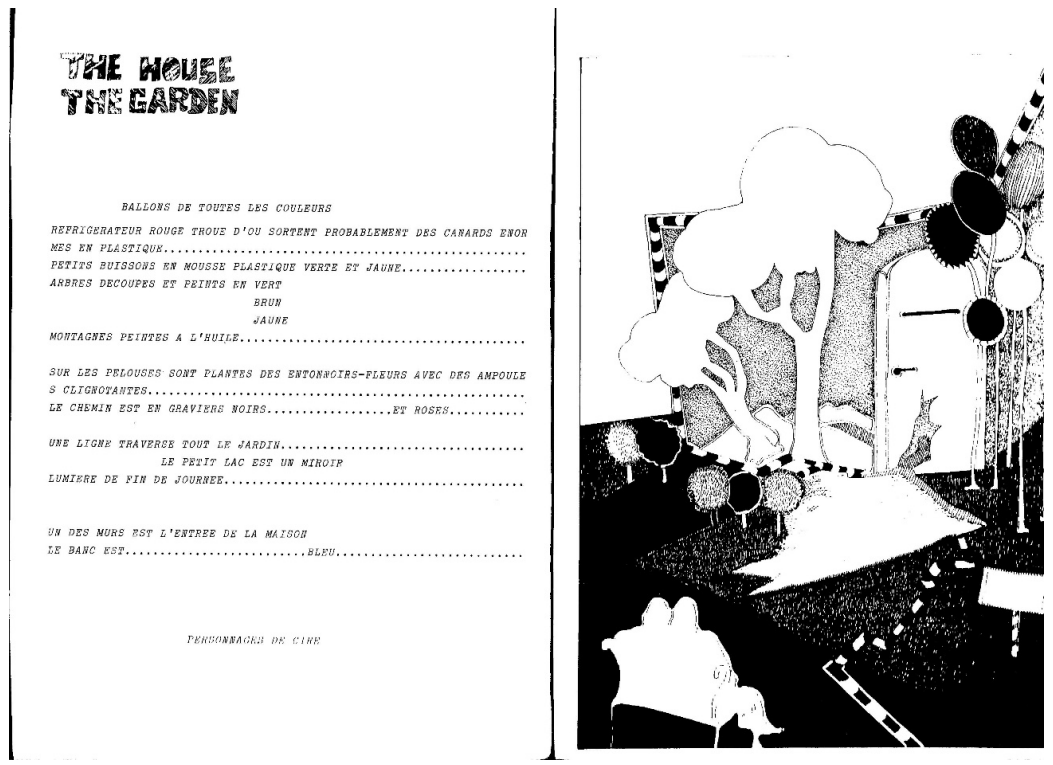

Figura 11. Projets 69 (AL BERTO, 2002).

Fonte: Fotografia do exemplar do autor. 


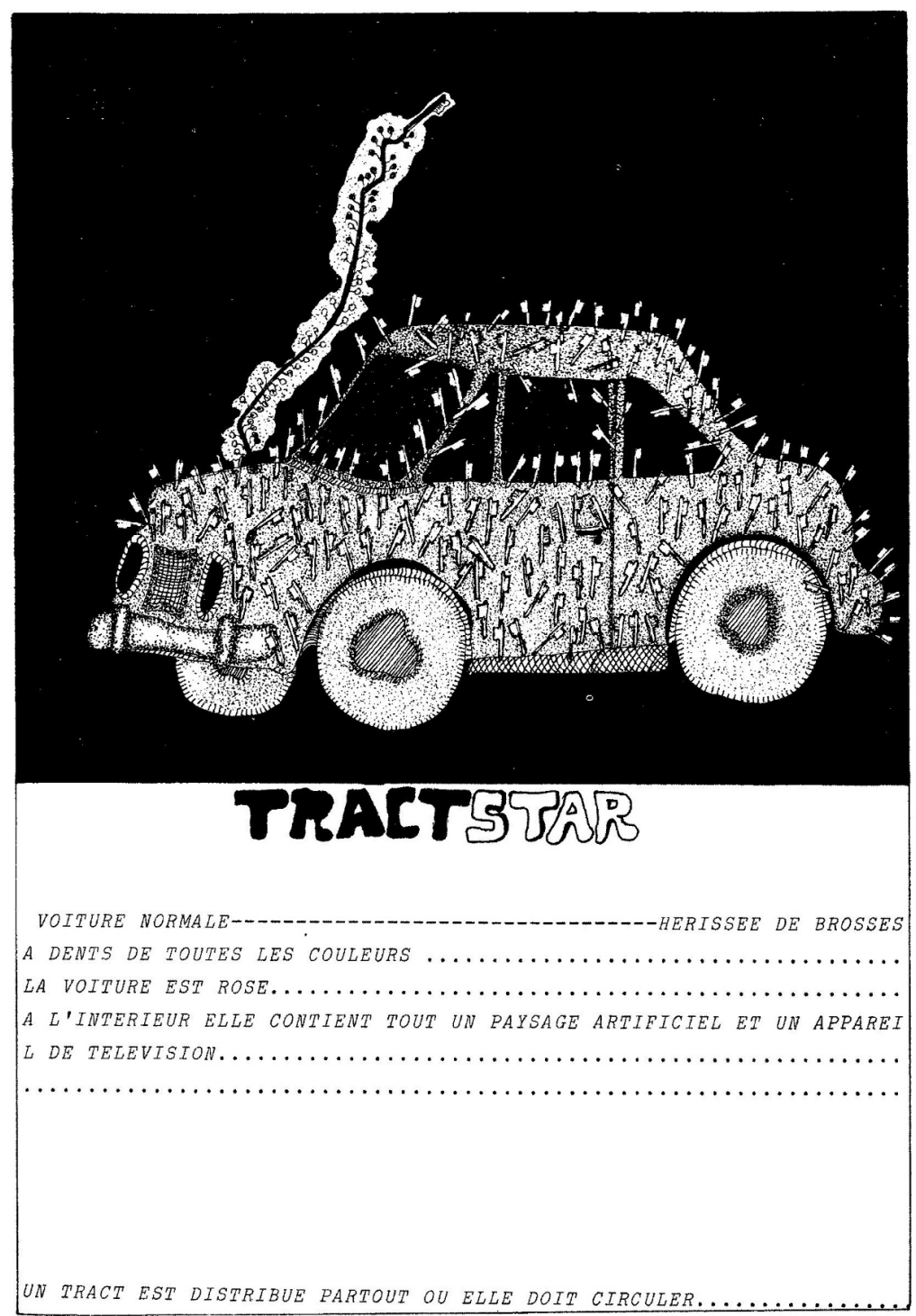

Figura 12. Projets 69 (AL BERTO, 2002).

Fonte: Fotografia do exemplar do autor. 
PROJETIFONTAI:E

TELEPHONE TUBE DE DENTIFRICE/EN MATIERE EZAZTQUE NOIRE ROUGE JAUNE LE TELEPHONE DOIT AVOIR UN SYSTEME DE SZ, TEZT QUI DECLANCHE LE CHA NGEIENT DE COULEUR DE L'EAU / A PLACEZ Z: JE GRANDES PELOUSES VER-

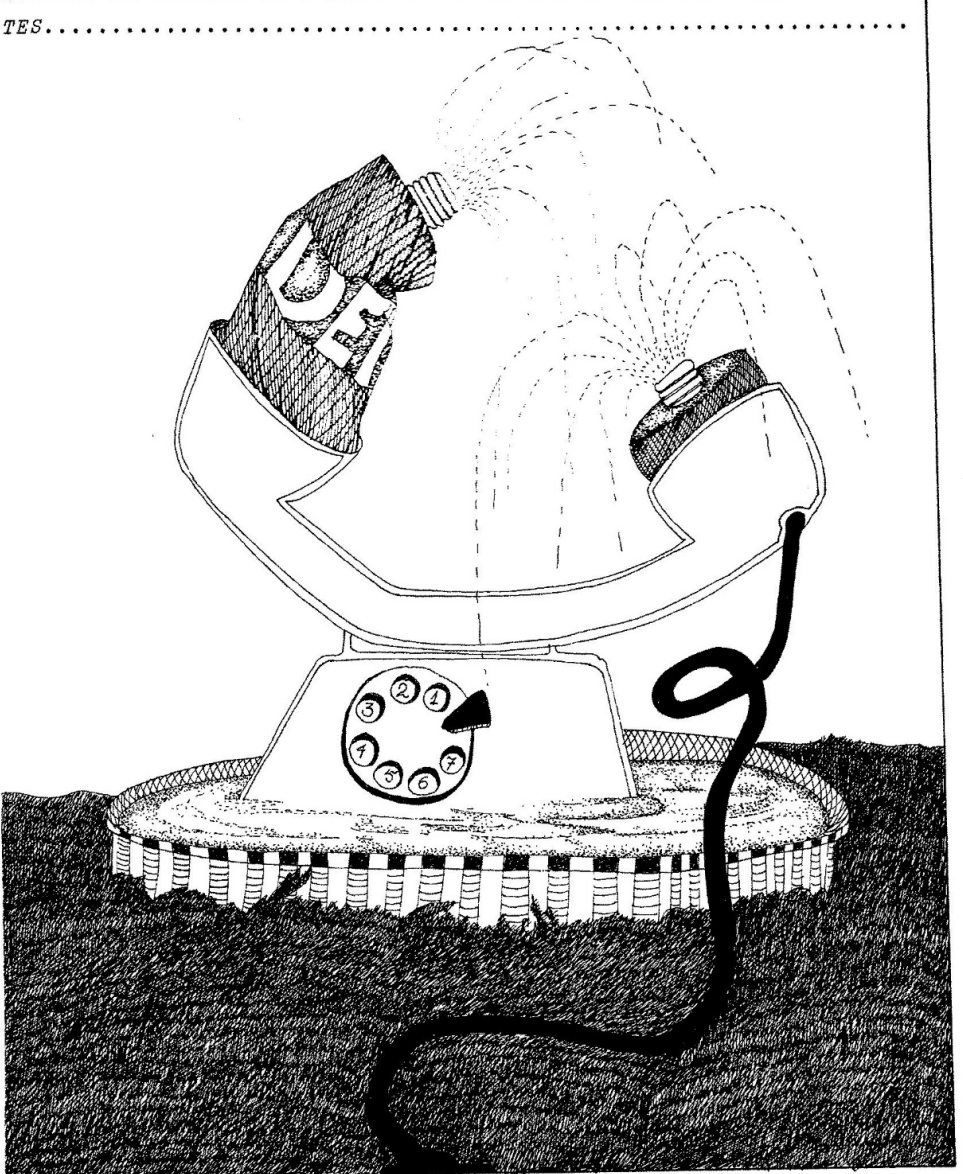

Figura 13. Projets 69 (AL BERTO, 2002).

Fonte: Fotografia do exemplar do autor. 
GRANDE BOITE SEXE CADEAU

A FLACER DANS UN CARREFOUR/ UN SYSTEME A Z'INERIEUR FERA RUNE COULEE D'UN PRODUTT ROSE QUT SE FEEANDRA PARTOUT

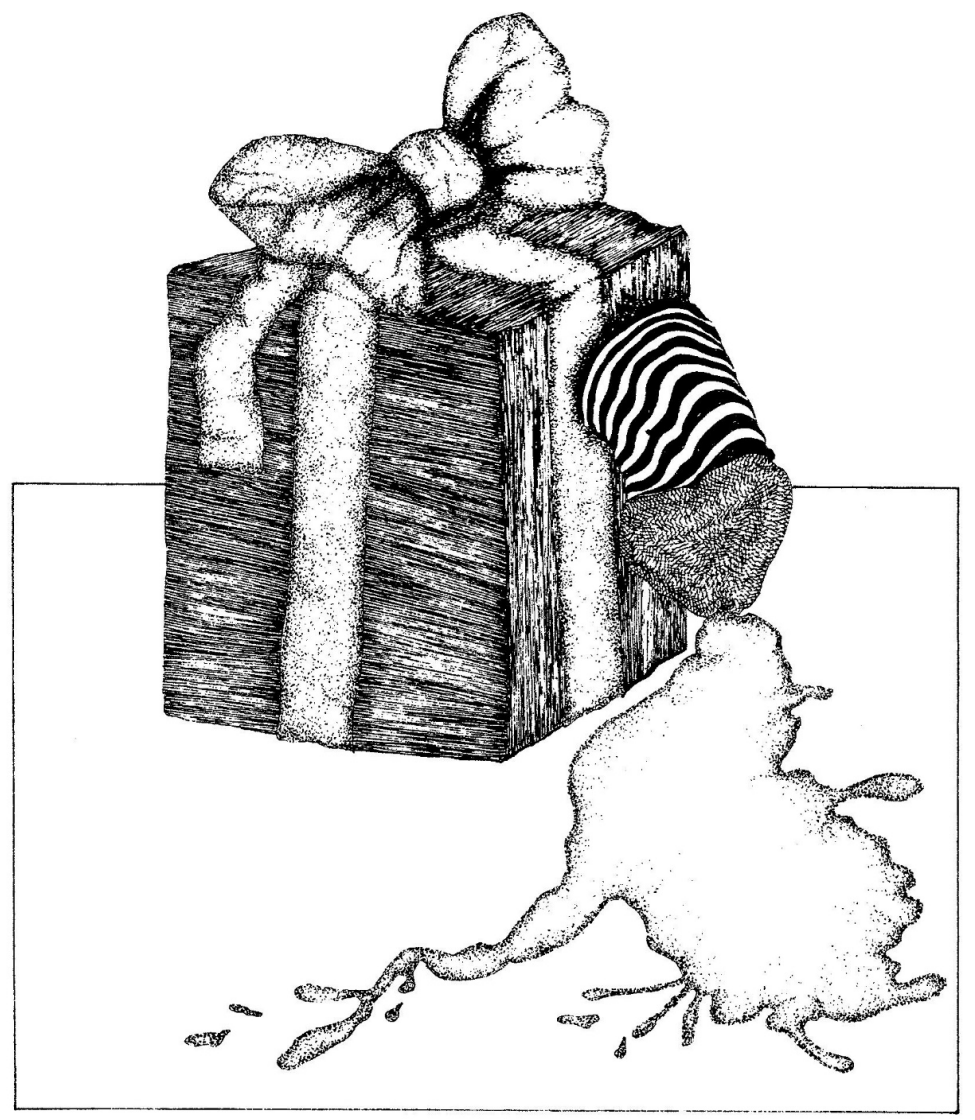

Figura 14. Projets 69 (AL BERTO, 2002).

Fonte: Fotografia do exemplar do autor. 


\section{LES CACAHUETES COLLAKTES}

즈 TOUTE UNE RUE SERA PLACEE UNE COUDE Z Z: CM DE CACAHUETES PEIN

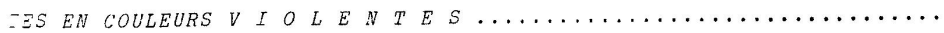

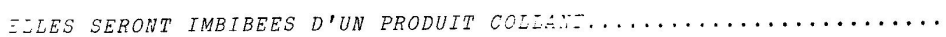

GUI LES FERA COLLER AUX CHAUSSURES PANTALONS...ETO..DES PASSANTS...

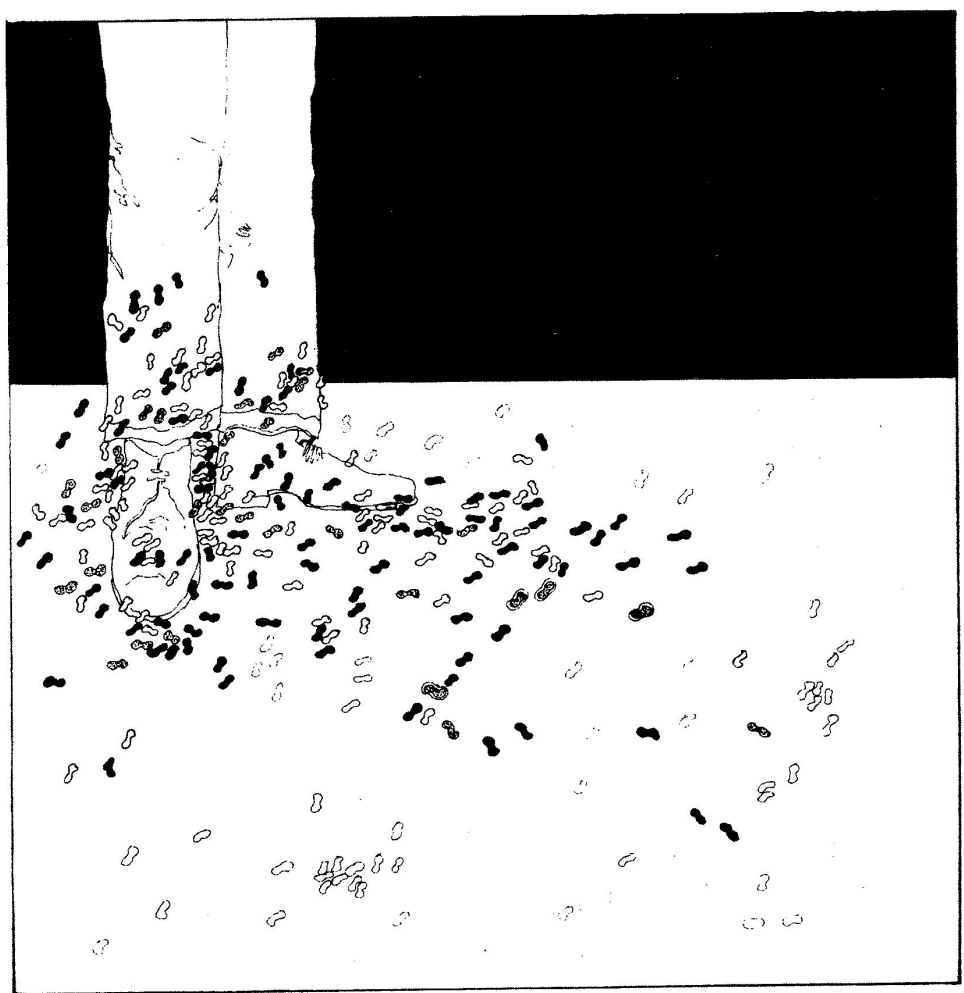

Figura 15. Projets 69 (AL BERTO, 2002).

Fonte: Fotografia do exemplar do autor. 


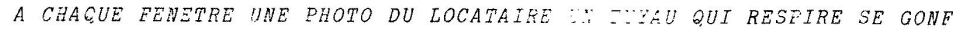
LE ET $\because E$ DEGONFE DE 2 M DE LARGE EATT C:.:工 ENTRE LES DEUX BATIME

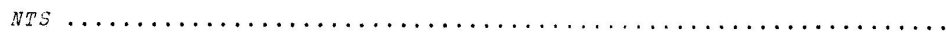

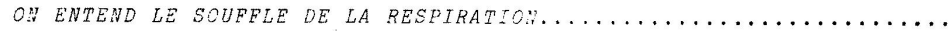

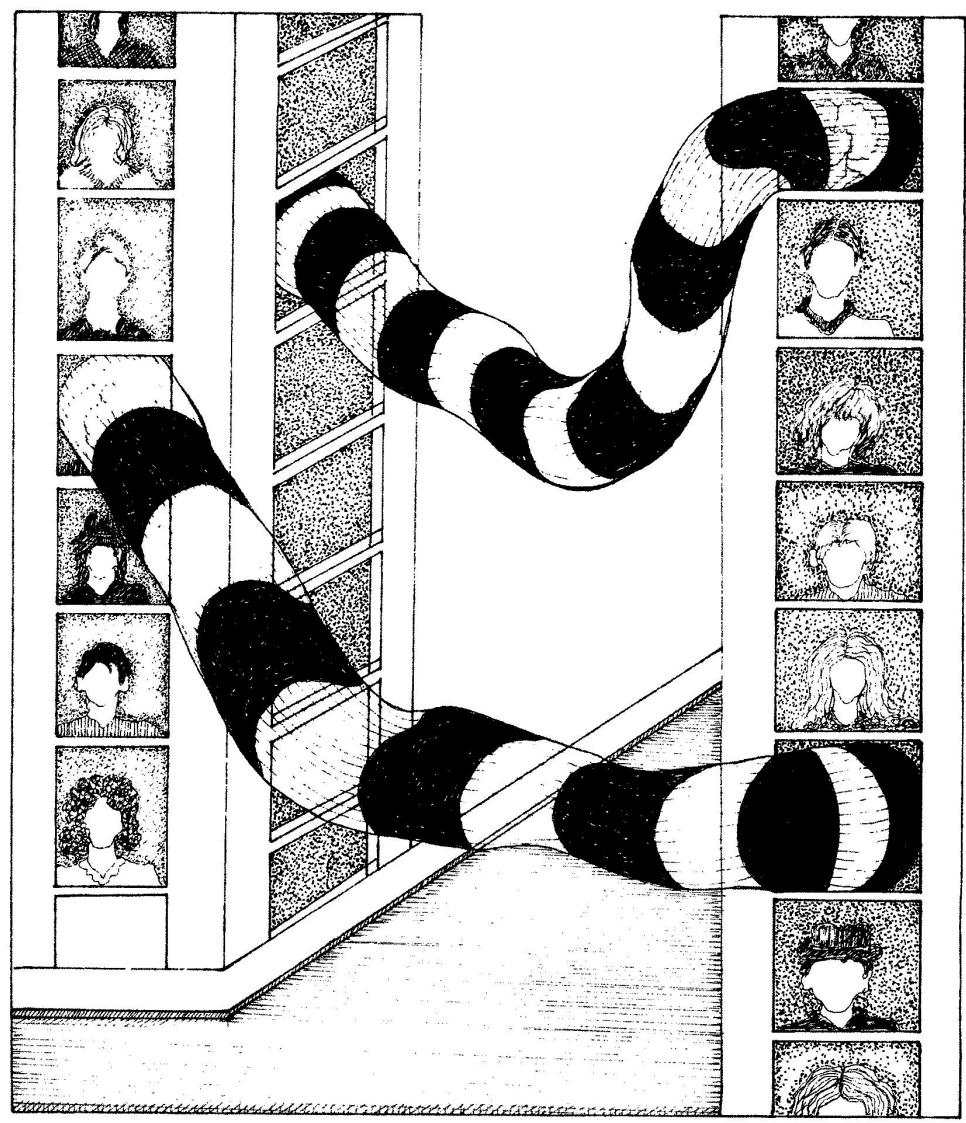

Figura 16. Projets 69 (AL BERTO, 2002).

Fonte: Fotografia do exemplar do autor. 
PROMENADE DANS LA MER

GRAND TUYAU POUR SE PROMENER DANS LA MER SOUS L'EAU/ LES MORCEAUX S UBMERGES SONT DE COULEUR DIFFERENTE /IL EST TRANSPARENT/ IL A UNE L ONGUEUR DE $1000 \mathrm{M}$ LARGEUR DE $2 \mathrm{M}$ AU BOUT ZU IUYAU UNE GRANDE SALLE

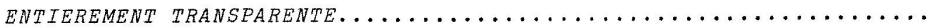

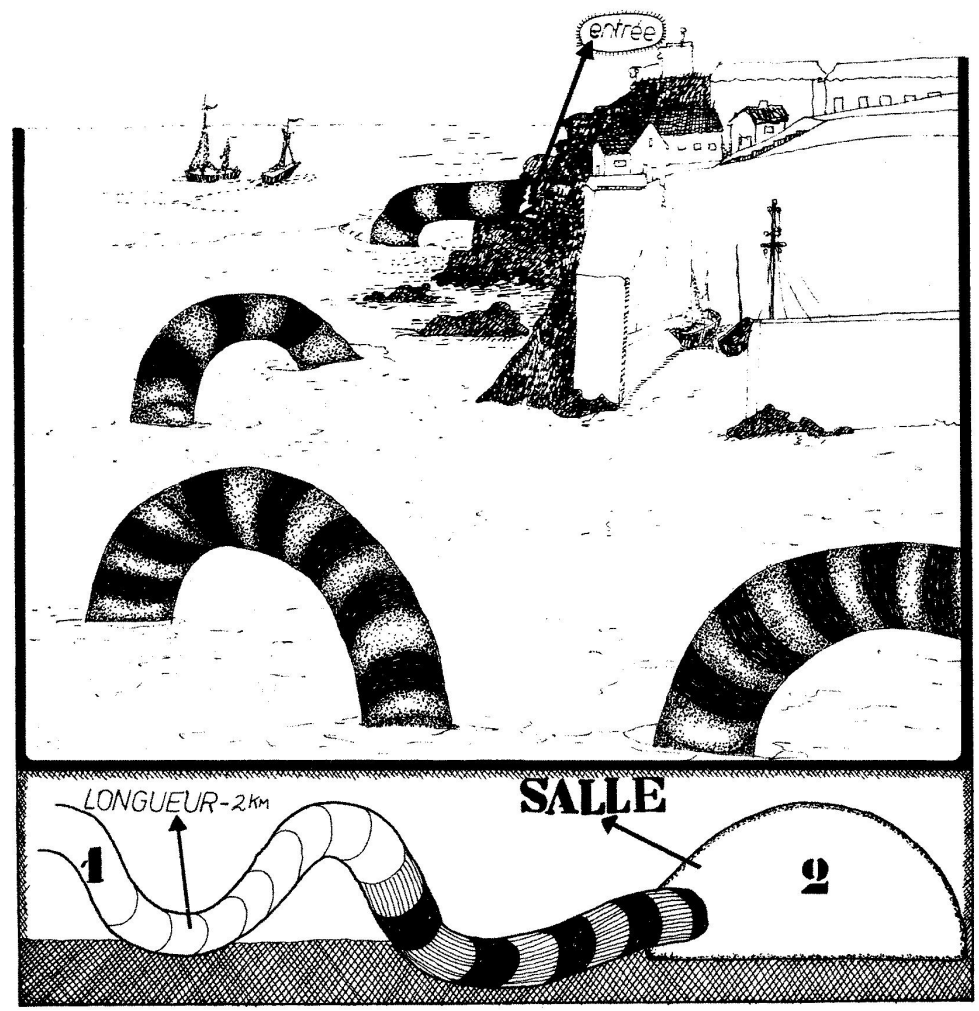

Figura 17. Projets 69 (AL BERTO, 2002).

Fonte: Fotografia do exemplar do autor.

Recebido: 17/01/2019

Aceito: 26/04/2019

Publicado: 2/08/2019

Remate de Males, Campinas-SP, v.39, n.1, pp. 191-218, jan./jun. 2019 - 218 